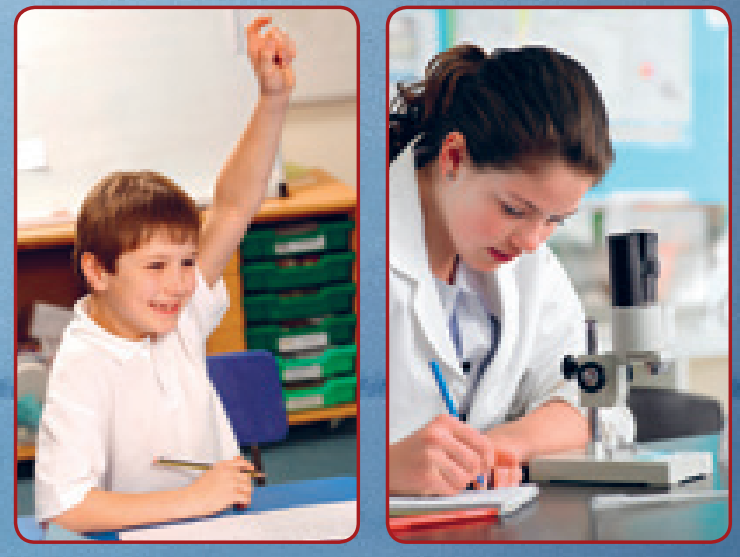

SEKTORPROGRAM

\title{
Uddannelse og forskning
}

Dansk formandskab for Nordisk Ministerråd 2015

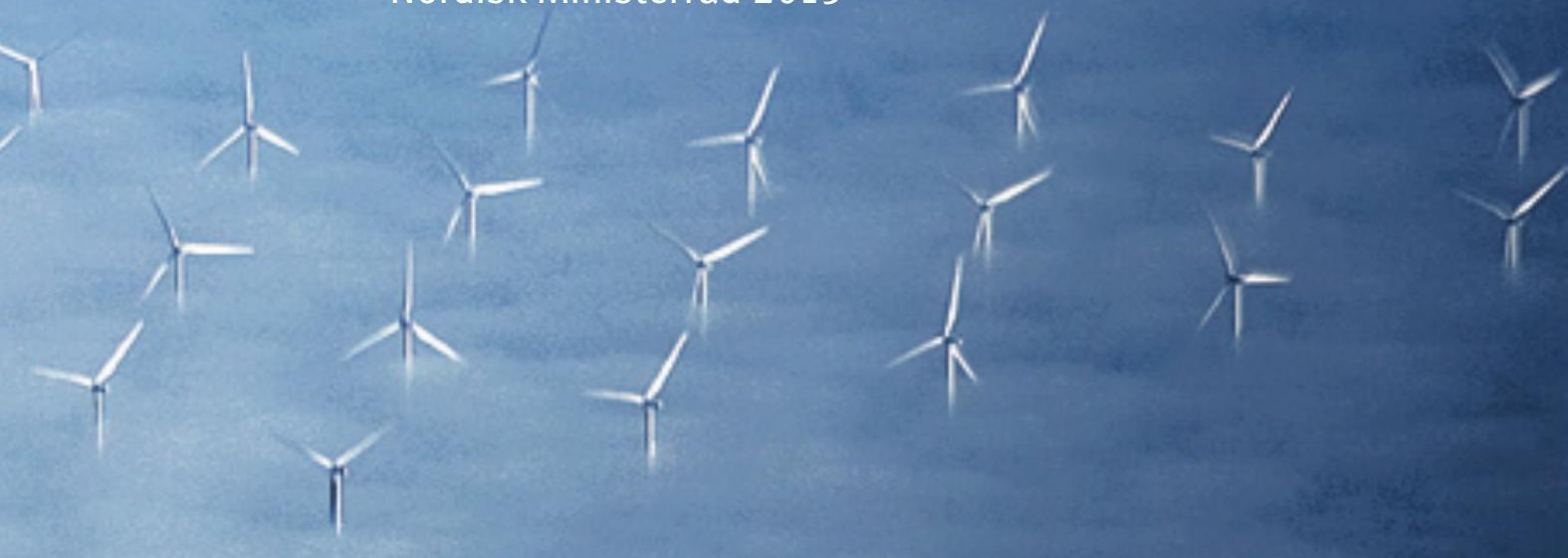


ISBN 978-92-893-3903-2 (PRINT)

ISBN 978-92-893-3904-9 (PDF)

http://dx.doi.org/10.6027/ANP2014-774

ANP 2014:774

(C) Nordisk Ministerråd 2014

Lillegrund Vindmøllepark Øresund, Danmark/Sverige

Layout: Erling Lynder

Omslagsfoto: Havvindmøller i Øresund,

Adrian Joachim og Signelements

Foto: s. 5 Les Kaner og Kim Vadskær; s. 6 og 8-9 Signelements; s. 11 og 14 Johannes Jansson; s. 18-19 Magnus Fröderberg Tryk: Rosendahls-Schultz Grafisk

Oplag: 500

Printed in Denmark

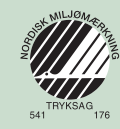

www.norden.org/da/publikationer

\section{Det nordiske samarbejde}

Det nordiske samarbejde er en af verdens mest omfattende regionale samarbejdsformer. Samarbejdet omfatter Danmark, Finland, Island, Norge og Sverige samt Færøerne, Grønland og Åland.

Det nordiske samarbejde er både politisk, økonomisk og kulturelt forankret, og er en vigtig medspiller i det europæiske og internationale samarbejde. Det nordiske fællesskab arbejder for et stærkt Norden i et stærkt Europa.

Det nordiske samarbejde ønsker at styrke nordiske og regionale interesser og værdier i en global omverden. Fælles værdier landene imellem er med til at styrke Nordens position som en af verdens mest innovative og konkurrencedygtige regioner.

\section{Nordisk Ministerråd}

Ved Stranden 18

1061 København K

Telefon (+45) 33960200

www.norden.org 


\section{norden}

SEKTORPROGRAM

\section{Uddannelse og forskning}

Dansk formandskab for Nordisk Ministerråd 2015

1 Forord

2 Indledning

3 Vækst

4 Velfærd

5 Værdier

6 Det Blå Arktis 


\section{Forord}

Det danske formandskabsprogram for Nordisk Ministerråd i 2015 stiller skarpt på temaerne vækst, velfærd, værdier og Det Blå Arktis.

Uddannelse, forskning og innovation spiller en central rolle i - og på tværs af - alle fire temaer.

De nordiske lande er tæt forbundne med fælles historie, kultur og værdier. Vores nordiske velfærdssamfund bygger på en demokratisk forståelse og en anerkendelse af ligeværd og lige rettigheder for alle og respekt for fællesskabet, som alle både bidrager til og nyder godt af. De nordiske lande er også kendetegnet ved, at vores uddannelsessystemer understøtter et sammenhængende børneliv og livslang læring. Det er fælles styrker og stærke nordiske værdier, der genfindes på tværs i vores uddannelsessystemer.

I de nordiske lande møder vi også en række fælles udfordringer. Vi er ikke gode nok til at bryde negativ social arv, sikre social mobilitet og inklusion af alle børn, unge og voksne i vores uddannelser og ligestilling af drenge i grundskolen og af kvinder i uddannelse og forskning.

At blive klogere og dygtigere er vigtigt i Norden. Alle skal blive så dygtige, som de kan. Langt de fleste klarer sig godt, men vi skal have alle med.

Derfor vil vi have fokus på et stærkt nordisk vidensamarbejde. Som et af Danmarks tre-årige formandskabsprojekter vil der inden for uddannelsesog forskningsområdet blive etableret et nordisk forum. Forummet skal styrke og sikre et struktureret vidensamarbejde inden for god pædagogisk praksis og god undervisning til brug for praktikere med henblik på at understøtte bedre faglige resultater, at betydningen af negativ social arv mindskes, og at børn og unge oplever en øget trivsel.

På samme måde har forskere en forpligtelse til at bringe deres viden $\mathrm{i}$ spil i samfundet. Nye forskningsresultater skal bruges til at udfordre de gældende standarder og metoder. Men forskningen skal nå bredere ud. Det kan være i form af formidling til den brede offentlighed for at højne indsigten hos den enkelte eller igennem konkret samarbejde med erhvervslivet for at skabe vækst og øget velfærd.

I de nordiske lande deler vi også en tradition for åbenhed og et ufravigeligt krav om excellence i vores tilgang til forskningen. De nordiske lande samarbejder på et højt fagligt niveau og bidrager til den globale vidensproduktion med forskere og artikler af høj international klasse. 
Der er således allerede et solidt fundament at udvikle uddannelsesog forskningssamarbejdet på. Og dette samarbejde bidrager til at løfte kvaliteten i uddannelserne samt at skabe en klarere nordisk profil i omverdenen.

Derfor skal vi fortsætte med at udvikle, udvide og styrke det nordiske samarbejde på uddannelses- og forskningsområdet, så der fortsat skabes en nordisk merværdi.

De centrale programmer på uddannelses og forskningsområdet Nordplus, Nordisk Masterprogram og NordForsk er med til at skabe gode rammer for mobilitet, erfaringsudveksling, kapacitetsopbygning og videndeling og bidrager samtidig til en styrket international profilering og positionering af Norden.

Gode uddannelser er en kerneværdi i vores nordiske samfund. Men gode uddannelser kommer ikke af sig selv. Og vi skaber dem ikke alene.

Vi skal bruge vores nordiske samarbejde til at nå endnu længere.

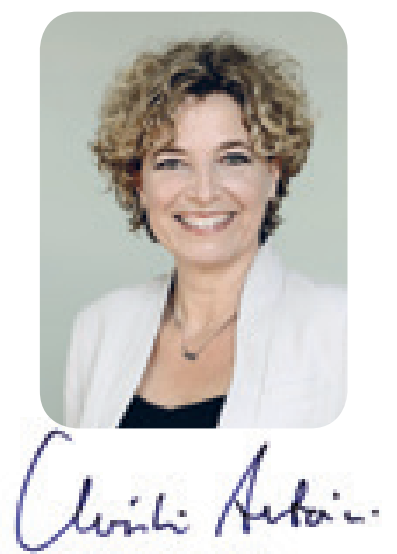

Christine Antorini

Undervisningsminister

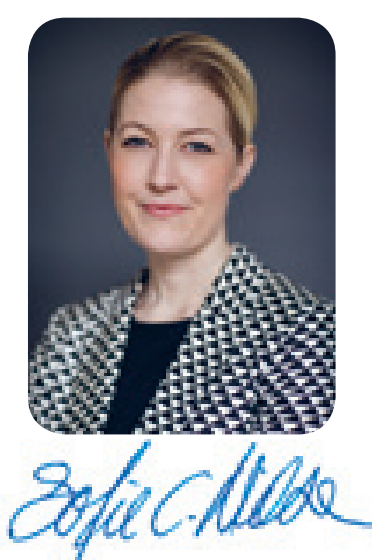

Sofie Carsten Nielsen Uddannelses-og forskningsminister 


\section{Indledning}

Styrket kvalitet i uddannelse og forskning bidrager til at skabe øget beskæftigelse og vækst og dermed bedre velfærd.

Men hvordan får vi udviklet dagtilbud, skoler, ungdomsuddannelser og videregående uddannelser, så der skabes større lighed? Hvorfor er vores uddannelser bedre tilpasset dem, der kommer fra hjem med mange bøger i reolerne? Hvorfor er der opstået et uddannelseshierarki, hvor det opleves som finere at vælge gymnasiet end en erhvervsuddannelse? Og hvorfor er der ikke flere kvinder i forskningen?

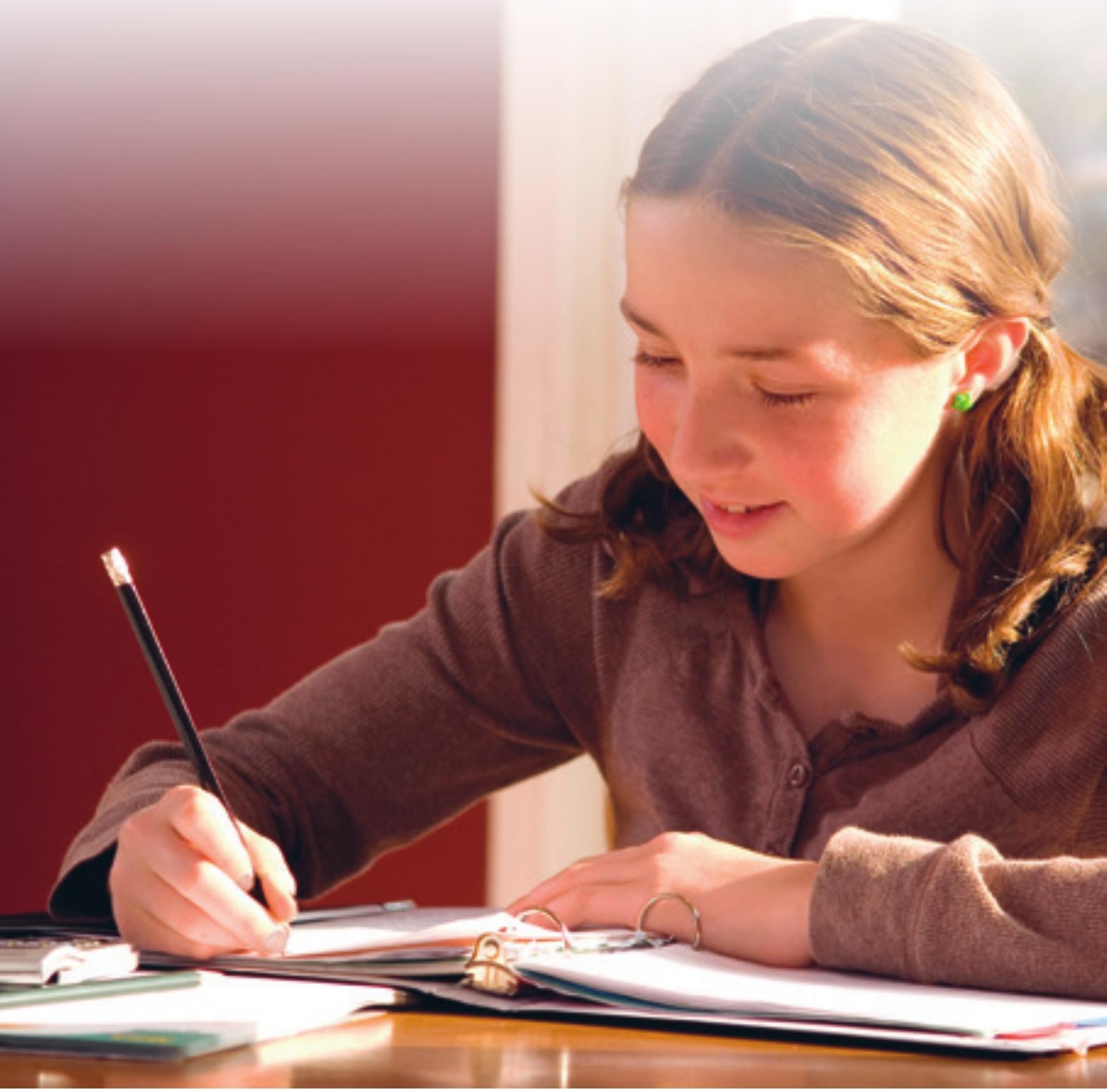


For mange børn, unge og voksne i Norden har stadig ikke tilstrækkelige faglige og sociale kompetencer til at klare en ungdomsuddannelse godt. F.eks. ses der et fald i børn og unges læselyst i alle fem lande, nordiske piger er stærkere læsere end nordiske drenge, og i alle lande på nær Finland er andelen af fagligt svage elever i både læsning, matematik og naturfag større end andelen af fagligt meget stærke elever. Alle de nordiske lande har oplevet et fald i elevernes resultater i PISA i matematik fra 2003 til 2012.

De nordiske uddannelsesinstitutioner opererer stadig mere i en global sammenhæng. Det medfører både nye udfordringer og muligheder. Hvordan opretholder vi - og øger - en nordisk mobilitet samtidig med, at nye muligheder ude i verden også åbner sig op? Hvordan håndterer de nordiske uddannelsesinstitutioner bedst den stigende interesse og efterspørgsel efter deres viden ude i verden?

Forskning er også en integreret del af et større samspil mellem offentlige og private aktører på den hjemlige arena og i internationalt regi. Dette samarbejde er vigtigt for at sikre innovation og vækst. Hvordan sikrer vi brobygning mellem forskningsmiljøer og erhvervslivet? Hvordan kan vi udvikle Norden til et internationalt kraftcenter for forskning og innovation og dermed styrke eksporten og tiltrækningen af udenlandske investeringer og talent?

Under det danske formandskab vil der blive sat fokus på nogle af disse problemstillinger i en nordisk kontekst gennem øget vidensog netværkssamarbejde, f.eks. inden for it-, statistik- og dataområdet, god pædagogisk praksis og god undervisning til brug for praktikere, videnskortlægninger, konkrete samarbejdsprojekter inden for udvalgte temaer af fælles nordisk interesse, øget mobilitet på uddannelses- og forskningsområdet og erfaringsudveksling på tværs af de nordiske lande.

\section{Yderligere information}

Det danske formandskab vil i løbet af 2015 afholde en række aktiviteter, konferencer, seminarer m.m., som knytter an til prioriteringerne i sektorprogrammet. Information om de enkelte tiltag vil løbende blive opdateret på formandskabets hjemmeside www.norden2015.dk samt på uvm.dk og ufm.dk. 


\section{Vækst}

Vi lever i en stadig mere globaliseret verden, hvor bl.a. handel, job og kommunikation går på tværs af landegrænser. En stor del af arbejdspladserne i de nordiske lande er afhængige af eksport. For også i fremtiden at have borgere, der kan agere sikkert som globale medborgere og en arbejdsstyrke, der kan navigere hjemmevant i en global verden, er det vigtigt, at vores nordiske uddannelser ruster vores børn, unge og voksne til dette.

En vigtig del i skabelsen af fremtidens uddannelser af høj kvalitet er derfor, at der er et internationalt udsyn i uddannelsen, og at der skabes et internationalt miljø i skolen og på studierne. Undersøgelser viser, at elever, der har været på udvekslingsophold mv. er mindre arbejdsløse, hurtigere får deres første job og hurtigere gør karriere end elever, der ikke har været ude. 
I Norden er det lykkedes at skabe internationale uddannelsesmiljøer på flere universitetsstudier blandet andet gennem Nordic Master programmet, der har ydet økonomisk støtte til etableringen af fællesnordiske kandidatuddannelser. Det danske formandskab ønsker at videreføre erfaringerne herfra til professionsbachelorområdet. Vi vil derfor igangsætte et arbejde, der skal løfte og udvide det nordiske samarbejde på velfærdsuddannelserne for både at fremme den nordiske mobilitet og sikre uddannelser af $h ø j$ kvalitet. Indsatsen vil ligge i forlængelse af Holdbar Nordisk Velfærd programmet, der har sat fokus på skabelsen af fremtidssikrede velfærdsuddannelser i Norden. 
Nordisk samarbejde om uddannelse medvirker ikke blot til at skabe nye internationale miljøer, men også til at skabe bæredygtige uddannelsesmiljøer af høj kvalitet. Bl.a. på små fagområder, hvor det på nationalt niveau kan være svært at opretholde et fagligt miljø af høj kvalitet. Derfor vil det danske formandskab have fokus på, at det nordiske samarbejde om udbud af små sprogfag fortsat udvikles og konkretiseres.

I Norden er der generelt en høj grad af uddannelsesmobilitet, men der er dog fortsat udfordringer. Eksempelvis er der store forskelle i mobilitetsstrømmene mellem de nordiske lande. Det nordiske program Nordplus giver mulighed for mobilitet fra dagtilbud til de videregående uddannelser i Norden, og er et meget vigtigt instrument i forhold til at understøtte mobiliteten i Norden, men skal ses i sammenhæng med EU's Erasmus+. Det danske formandskab vil derfor sætte fokus på, hvordan den nordiske uddannelsesmobilitet bedst sikres fremover.

En anden meget væsentlig faktor for øget vækst i de nordiske lande er uddannelsernes kobling til praksis og arbejdspladsernes behov. Det er vigtigt både for kvaliteten, og for at uddannelserne er attraktive. Inden for det nordiske samarbejde er der sat særlig fokus på arbejdspladslæring i erhvervsrettet ungdomsuddannelse, hvor alle lande arbejder med kvalitetsudvikling. Det danske formandskab vil bidrage til udveksling af erfaringer og dialog om kvalitetsudvikling og indretning af fremtidens erhvervsuddannelser.

I de nordiske lande spiller gode grundlæggende færdigheder hos alle også en central rolle for deltagelse i livslang læring, og for hvordan man klarer sig på arbejdsmarkedet $\mathrm{i}$ et moderne videns-og produktionssamfund. De nordiske lande ligger i top, når det gælder voksenuddannelse, men er også udfordret af, at en del borgere ikke har de fornødne grundlæggende færdigheder til fuldt ud at kunne deltage aktivt $\mathrm{i}$ samfundet. Det danske formandskab vil i samarbejde med Nordisk Netværk for Voksnes Læring (NVL) medvirke til at styrke nordisk samarbejde om, hvordan vi tilgodeser voksnes forskellige behov for udvikling af gode, grundlæggende færdigheder.

I forhold til OECD's PIAAC Programme (Programme for the International Assessment of Adult Competencies) er der med støtte fra Nordisk Ministerråd, i regi af et nordisk netværk om PIAAC, etableret en nordisk PIAAC database og gennemført en række nye analyser af voksnes kompetencer. Det danske formandskab vil i samarbejde med det nordiske PIAAC-netværk bidrage til, at den ny viden bringes i spil. Det vil bl.a. ske 
på en konference i foråret 2015, der har til formål at skabe et øget fælles nordisk fokus på og stimulere til nye uddannelses - og forskningsinitiativer på voksenområdet.

Endvidere vil der i samarbejde med Nordisk Netværk for Voksnes Læring (NVL) blive nedsat en arbejdsgruppe i 2015, der skal fastlægge rammer, fokusområder og initiativer for et nyt nordisk netværk om voksnes basale færdigheder. Formålet er, at arbejdsgruppen skal styrke nordisk erfaringsudveksling og dialog om udvikling af voksenuddannelsestilbuddene.

Digitalisering har stor betydning for den kommende vækst i samfundet, og derfor er der behov for cyber- og informationssikkerhed. Cyber- og informationssikkerhedstrusler er ofte af grænseoverskridende karakter, hvorfor det vil være hensigtsmæssigt at samarbejde med ligesindede lande om en styrkelse af uddannelses- og forskningsindsatsen på området.

I de kommende år vil en af verdens største og mest avancerede forskningsfaciliteter blive bygget i Norden. European Spallation Source (ESS), som faciliteten hedder, er en neutronspredningsfacilitet, der fungerer som et kæmpestort og meget avanceret mikroskop, der giver unikke muligheder for at undersøge materialer fra den mindste atomare struktur til hele maskindele i fuld størrelse og drift. Etableringen af ESS i Norden er et unikt fremskridt for det nordiske forskningssamarbejde, som vi under formandsskabet vil bygge videre på. 
For at indfri ESS's fulde potentiale inden for vækst og produktivitet i de nordiske lande kræves der en helt konkret kompetenceopbygning og brobygning mellem ESS, forskningsmiljøer og erhvervsliv i de nordiske lande. Dette er en prioriteret opgave for det danske formandskab.

En væsentlig del af værdiskabelsen i de nordiske lande finder sted i såkaldte klynger, hvor virksomheder, forsknings- og uddannelsesinstitutioner og offentlige institutioner samarbejder tæt om at udvikle viden, som virksomhederne kan anvende til at skabe nye produkter og services. I Norden har vi bl.a. stærke klynger inden for vedvarende energi, miljøteknologi, offshore, sundhed og velfærdsteknologi, smart it, fødevarer, transport mv.

Hver for sig er de nordiske klynger imidlertid små, set i et globalt perspektiv. Hvis vi derimod forener kræfterne inden for vores styrkepositioner, vil Norden kunne udgøre et internationalt kraftcenter, som kan styrke både eksporten og tiltrækning af udenlandske investeringer og talent.

Det er derfor en prioriteret opgave for det danske formandskab at styrke klyngesamarbejdet mellem de nordiske lande og herunder fokusere på at styrke de små og mellemstore virksomheders innovation og internationalisering.

\section{Danmark vil under sit formandskab:}

- Stille forslag om nedsættelse af en arbejdsgruppe med eksperter fra institutioner og ministerier, der under det danske formandskab skal komme med forslag til konkrete samarbejdsprojekter på de nordiske professionsbacheloruddannelser - herunder læreruddannelsen - i form af eksempelvis fællesnordiske moduler eller praktikpladssamarbejde.

- Prioritere og understøtte det arbejde der er sat i gang med henblik på at fremme et forpligtende nordisk samarbejde om udbud af små fag, herunder særligt de små sprogfag og sikre fremdrift på dette område.

- Følge op på de igangsatte evalueringer af Nordplus, Overenskomsten for Adgang til Videregående Uddannelser og Reykjavikdeklarationen, og i regi af den nordiske Embedsmandskomite for Uddannelse og Forskning (EK-U) drøfte, hvordan den nordiske mobilitet fortsat kan udvikles og styrkes. 
- Afholde en konference om arbejdspladsbaseret læring i Norden foråret 2015, Nytænkning i praktikken med respekt for traditionerne. Konferencen vil stille skarpt på, hvordan vi får en bedre sammenhæng mellem skole- og arbejdspladslæring i erhvervsuddannelserne i forhold til såvel de unge som de voksne.

- Medvirke til afholdelsen af en konference i samarbejde med det nordiske PIAAC netværk for forskere og praktikere om de nordiske PIAAC-resultater, hvor ny nordisk forskning om voksnes basale færdigheder fremlægges, drøftes og perspektiveres.

- Samarbejde med Nordisk Netværk for Voksnes Læring (NVL) om at igangsætte en arbejdsgruppe, der skal fastlægge rammer, fokusområder og initiativer for et nyt netværk om voksnes basale færdigheder.

- Igangsætte en dialog i regi af Embedsmandskomiteen for Uddannelse og Forskning (EK-U) om mulighederne for at styrke samarbejdet mellem uddannelses- og forskningsinstitutioner på området for cyber- og informationssikkerhed.

- Arrangere en kick-off konference for neutronforskningsprogrammet med fokus på, hvordan ESS kan udnyttes i forhold til at løse store samfundsmæssige udfordringer.

- Skabe et nordisk ESS-netværk for industrien. Projektet vil have fokus på konkret opbygning af viden, kompetencer og teknologi i industrien, herunder primært små og mellemstore viden-intensive virksomheder.

En lang række brancher og virksomheder kan drage nytte af samarbejde omkring ESS.

- I samarbejde med Nordisk Ministerråd arrangere et stort nordisk-baltisk matchmaking event, hvor 150-200 klynger mødes med henblik på at etablere nye, grænseoverskridende samarbejder til gavn for små og mellemstore virksomheder i de nordiske lande.

- Tage initiativ til, at de nordiske-baltiske lande i fællesskab understøtter etablering af et antal grænseoverskridende klynge-til-klynge samarbejdsprojekter inden for områder, hvor nordiske små og mellemstore virksomheder (SMV'er) har store vækst- og innovationspotentialer. Der sigtes mod at gennemføre et fælles projektopslag med titlen Innovation Express i regi af Baltic Sea Region Stars-samarbejdet. 


\section{Velfærd}

Talent kan findes alle steder og skal have mulighed for at udfolde sig uagtet social baggrund. De nordiske samfund er relativt små og har ikke råd til, at børn og unge ikke får mulighed for at indfri deres potentiale. Derfor vil der under det danske formandskab blive sat fokus på videns- og erfaringsudveksling om social mobilitet.

Alle lande er optaget af at skabe de bedste uddannelser for deres befolkning. Gode uddannelser er med til at skabe beskæftigelse, velfærd og trivsel. Dette gælder også for de nordiske lande. Men internationale undersøgelser viser, at der er udfordringer med bl.a. faglighed og trivsel i de nordiske lande. Det betyder, at elever, studerende og lærere i stigende grad oplever, at der igangsættes reformer af uddannelsers indhold og rammer.

Reformer på uddannelses- og forskningsområdet stiller krav til en stor kulturforandring i dagtilbud, skoler og andre uddannelsessteder. Det gælder både i forhold til indholdet i pædagogikken og undervisningen, i uddannelsesstrukturen, ledernes rolle og til pædagogers, læreres og underviseres samarbejdsformer og tilstedeværelse. Vi ved, at der er langt fra reformer på papiret til undervisningen i klasseværelset eller auditoriet.

Vigtige rettesnore i forhold til virkeliggørelse af reformer er bl.a. en tæt dialog mellem de relevante aktører, at initiativer bygger på viden, at der er vejledning og gode it-understøttede redskaber til de medarbejdere og chefer der skal løfte opgaven lokalt, og at man fra lokalt og centralt hold følger fremdriften i reformerne.

I en reformproces på uddannelsesområdet er pædagoger, lærere og undervisere de vigtigste forandringsagenter. Danmark vil sætte særligt fokus på, hvordan professionerne kan støttes i reformarbejdet og dermed de forandringsprocesser, der skal til for løbende at være klædt på til at virkeliggøre de forskellige reformtiltag. I den forbindelse er det vigtigt at sikre deling af viden fra både nordiske og internationale skolesystemer, der har erfaring med en systematisk evalueringsindsats, f.eks. som opfølgning på OECD’s TALIS undersøgelse for lærere og skoleledere. TALIS står for Teaching and Learning International Survey, og undersøgelsen giver bl.a. værdifuld viden om, hvilke former for evaluering og feedback, der anvendes på skolerne og om lærernes behov for faglig og professionel udvikling m.m.

Reformernes fokus på uddannelserne skal også sikre et fokus på de børn og unge, som af forskellige årsager kan blive klemt i de mange reformer. Derfor er det vigtigt hele tiden at have et spor, hvor fokus holdes på at sikre og udvikle muligheder for børn og unge i udsatte positioner. 
Videns- og erfaringsudveksling og inddragelse af praktikerne er essentielt, hvis reformerne skal lykkes.

Inden for uddannelses- og forskningsområdet bliver der derfor som led i et tre-årigt formandskabsprojekt "Viden, der gør børn og unge dygtige og livsduelige - Nordisk videnssamarbejde om god undervisning og god pædagogisk praksis til brug for praktikere" etableret et nordisk forum. Dette forum skal styrke og sikre et struktureret vidensamarbejde inden for god pædagogisk praksis og god undervisning til brug for praktikere med henblik på at understøtte bedre faglige resultater, at betydningen af negativ social arv mindskes, og at børn og unge oplever en øget trivsel.

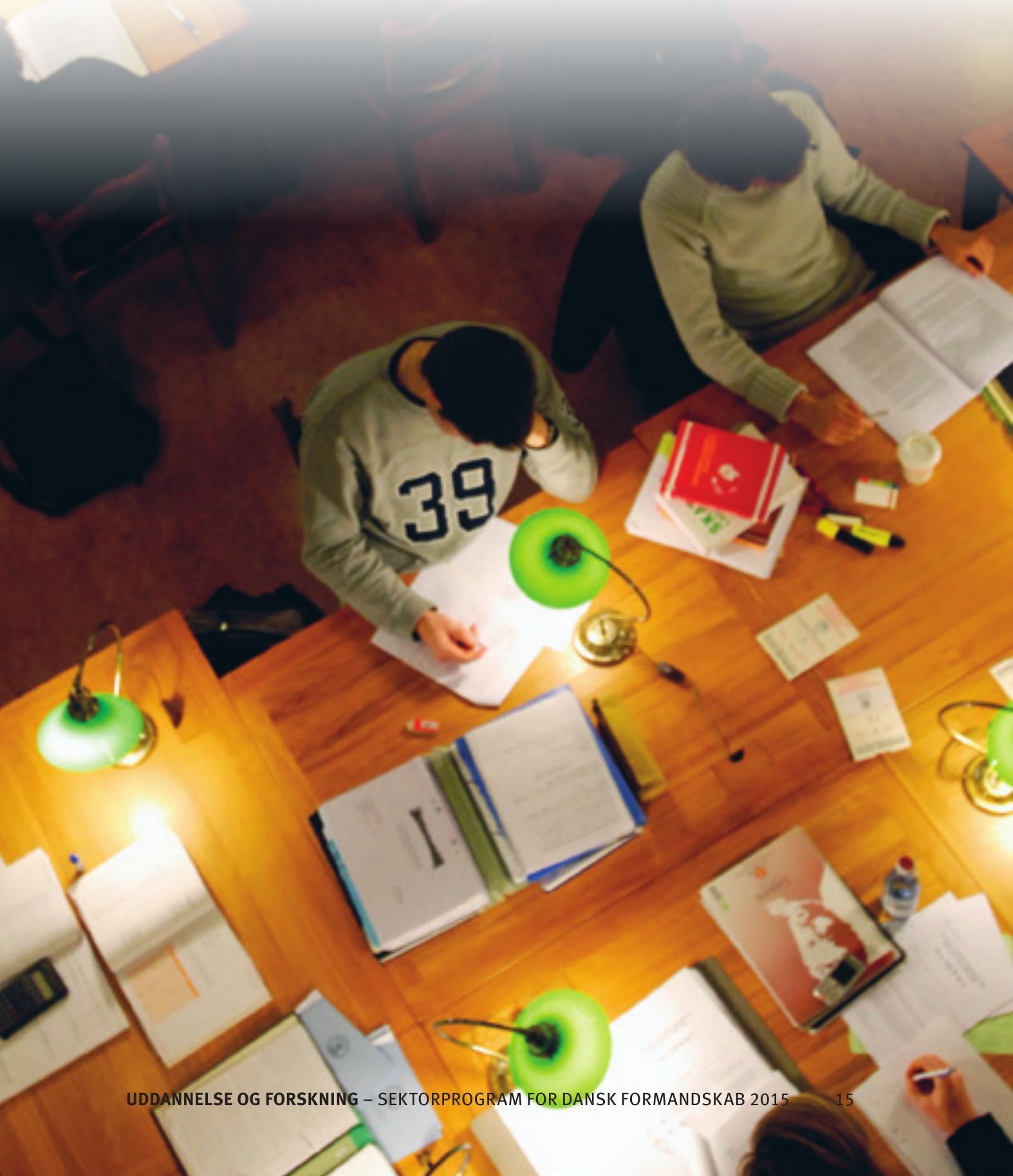


Der er mange styrker i nordisk pædagogik og uddannelse, f.eks. stor grad af fokus på demokrati, lighed og medskabelse, og vores samfund minder kulturelt, sprogligt og organisatorisk meget om hinanden. Det betyder, at vi har et godt grundlag for at lære af hinandens erfaringer og de enkelte landes forskning. Vi skal derfor styrke samarbejdet om at kortlægge, udvikle og formidle viden på tværs af Norden til praktikere, så pædagoger og lærere får det bedst mulige vidensgrundlag for gennem samvær, pædagogiske aktiviteter og undervisning at gøre en forskel i forhold til børnene og de unge.

Det nordiske forum skal i sit arbejde bl.a. have fokus på at styrke landenes samlede indsats for at indsamle data og viden om gode, effektive metoder i forhold til identificerede udfordringer fra hele Norden, sikre at viden er tilgængelig og praktikeranvendelig på eksisterende portaler, at viden omsættes samt understøtte praksisnetværk, igangsætte praksis- og forskningskortlægninger, der har en generel nordisk interesse, samt at vurdere muligheden for at udvikle målemetoder i forhold til nordisk værdsatte kompetencer som bl.a. innovation, kreativitet og entreprenørskab.

Et andet konkret forslag til nordisk videndeling er at nedsætte en nordisk netværksgruppe med henblik på at styrke det nordiske netværkssamarbejde inden for statistikområdet om indhold og kvaliteten af kvantitative indikatorer i Norden. Danmark deltager sammen med bl.a. de øvrige nordiske lande i OECD-samarbejdet om udvikling og implementering af internationale indikatorer til publikationen Education at a Glance. Der er nedsat en række netværksgrupper i OECD, som drøfter, hvordan man fortsat kan forbedre eksisterende samt udvikle sammenlignelige nye indikatorer, der beskriver uddannelsessystemet og dets indflydelse på beskæftigelse og andre forhold, som ikke nødvendigvis afspejler den nationale uddannelsesstruktur. Netværket kunne derfor have til formål at udvikle en fælles nordisk forståelse af hvilke data, der anvendes og for at skabe bedre sammenlignelige nordiske data. Resultatet kunne være en særlig nordisk pixi-udgave af udvalgte indikatorer fra Education at a Glance.

Nordisk Ministerråds program Holdbar Nordisk Velfærd inden for uddannelse og arbejde og forskning for velfærd arbejder tillige med nordiske platforme for dialog og vidensudveksling. Det danske formandskab vil derfor bidrage til, at der sikres en god afrunding af og opfølgning på relevante indsatser i regi af programmet, der udløber ved udgangen af 2015. 


\section{Danmark vil under sit formandskab:}

- Initiere en dialog på ministerniveau om, hvordan den sociale mobilitet på uddannelsesområdet styrkes i Norden og sikre, at alle talenter kan udfoldes, herunder udveksle erfaringer landene i mellem.

- Prioritere og understøtte det arbejde, der er igangsat under Islands formandskab i 2014 om kompetenceudvikling på pædagog- og lærerområdet.

- Initiere en dialog på ministerniveau om, hvordan pædagog- og lærerprofessionen udvikles, så pædagoger og lærere kan håndtere de fremtidige udfordringer i grundskolen - både under deres grunduddannelse, i efter- og videreuddannelsesregi og anden kapacitetsopbygning.

- Invitere til et to-dages seminar om, hvordan vi får skabt en systematisk, meningsfuld og stærk evalueringskultur i grundskolen.

- Etablere et tværnordisk forum som led i formandskabsprojektet, der skal styrke det nordiske samarbejde om at udvikle og anvende viden, så god undervisning og god pædagogisk praksis i endnu højere grad gør børn og unge så dygtige de kan, og at børn og unge oplever en $\emptyset$ get trivsel.

- Invitere til et kick-off seminar i forbindelse med det nordiske vidensamarbejdsprojekt.

- Nedsætte en nordisk netværksgruppe med henblik på at styrke det nordiske netværkssamarbejde inden for statistikområdet.

- Invitere til et nordisk uddannelsesdirektørmøde fra dagtilbudsområdet til de videregående uddannelser.

- Prioritere, at der sikres en opfølgning på igangsatte indsatser i regi af Holdbar Nordisk Velfærd programmet, herunder indsatsen for at fremme entreprenørskab i grundskole og ungdomsuddannelser.

- Afholde en række initiativer på børne- og ungdomsområdet i regi af Nordisk Børne- og Ungdomskomité (NORDBUK) med henblik på at afdække udfordringer og muligheder for børn og unges fortsatte demokratiske deltagelse i de nordiske lande. 


\section{Værdier}

Norden er også kendt i verden for et uddannelsessystem af høj kvalitet og nordiske uddannelser efterspørges i omverdenen - bl.a. dansk pædagogik, de duale erhvervsuddannelser, velfærdsuddannelser, og voksen/efteruddannelse, hvor vi i Norden har en særlig ekspertise. Derfor er uddannelseseksport også et emne, der i stigende grad bliver aktuelt i de nordiske lande i takt med, at omverdenen efterspørger de nordiske uddannelser.

Uddannelseseksport er et område med stort potentiale. Aktører på området fremhæver, at uddannelseseksport bidrager til at fremme internationalisering af egne uddannelser, styrker kvaliteten i egne uddannelser, skaber vækst for nordiske virksomheder i udlandet samt indtjening til de nordiske samfund. 
Men samtidig er det et nyt område at bevæge sig ind på for mange uddannelsesinstitutioner. De nordiske uddannelsesinstitutioner har både fællesnævnere i forhold til ekspertiseområder, der gør dem attraktive for uddannelseseksport - f.eks. velfærdsuddannelser, den nordiske pædagogiske tradition og erhvervsuddannelser i Danmark - og har desuden nogle af de samme udfordringer grundet lighederne i de nordiske uddannelsessystemer, hvilket bl.a. handler om sproglige barrierer og manglende kommerciel kultur. Derfor vil det danske formandskab tage initiativ til en nordisk konference om udveksling af erfaringer og ideer for at styrke de nordiske uddannelsesinstitutioners muligheder.

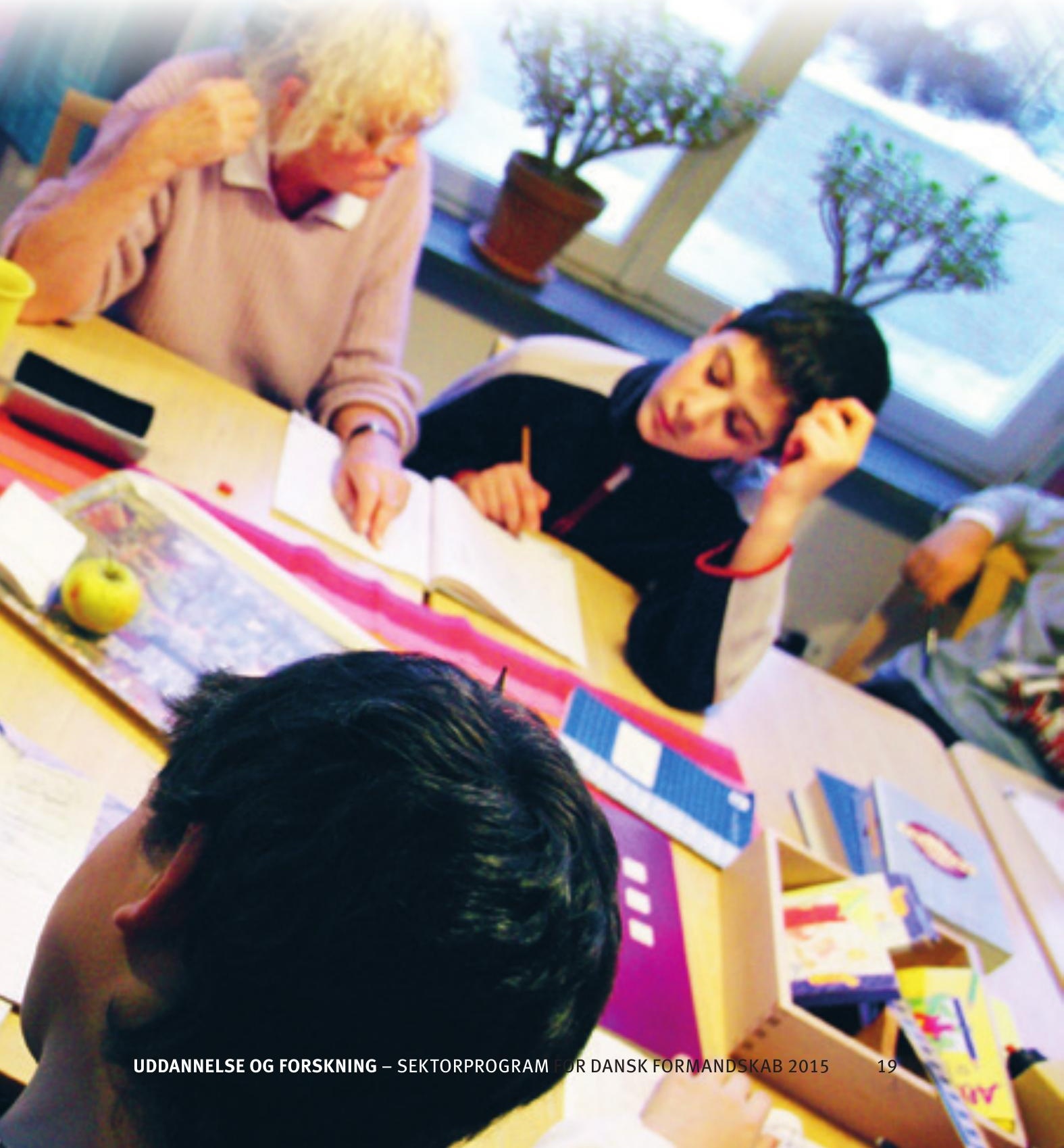


Kønsbalancen i forskning udgør en vigtig forskningspolitisk problematik på globalt plan. Samlet set er Norden kendt for at være kommet langt, når det gælder ligestilling mellem kvinder og mænd. Til trods for dette er 80 procent af professorerne i Norden fortsat mænd, hvilket indikerer, at vi i Norden ikke i tilstrækkelig grad udnytter den samlede talentmasse. De nordiske lande ser ud til at have forskellige strategier til at fremme kønsbalancen, og der er forskelle mellem landene, når det gælder kønssammensætning blandt forskere. Den politiske prioritering af spørgsmålet og den politiske vilje til styring og overvågning af ligestillingsarbejdet $i$ forskningsmiljøerne varierer også mellem landene. På den baggrund tog det norske formandskab for Nordisk Ministerråd i 2012 initiativ til rapporten Norden - et steg nærmere kjønnsbalanse i forskning? Rapporten og problemstillingerne heri blev fulgt op på et seminar i regi af NordForsk i efteråret 2014. Det danske formandskab vil tage initiativ til at videreføre denne nordiske dialog på ministerniveau, således at de nordiske lande kan fortsætte med at lære af hinandens erfaringer på området.

I de nordiske uddannelsessystemer ses der fortsat kønsopdelte uddannelsesvalg. Talentmasse bør udnyttes bedst muligt, og piger og drenge bør vælge uddannelse efter kompetencer og kvalifikationer og ikke efter køn. Et brud med det kønsopdelte uddannelsesvalg vil medvirke til, at alle talenter kommer i spil. I regi af Nordisk Ministerråd for Ligestilling (MR-JÄM) igangsættes der derfor en indsats med fokus på det kønsopdelte uddannelsesvalg. Denne indsats vil blive fulgt og koblet til indsatserne i Ministerrådet for Uddannelse og Forskning (MR-U).

Som opfølgning på den fælles nordiske konference Norden viser vej, der blev holdt i januar 2014 som led i det fælles nordiske skoleprojekt initieret af det nordiske Ministerråd for Uddannelse og Forskning (MR-U), vil Danmark under sit formandskab sætte fokus på mulighederne for at etablere venskabsklasser og udveksling i øvrigt og for at danne nye nordisk netværk for institutioner og skoler, der har lyst til at indgå i et netværkssamarbejde om at løse lokale udfordringer på tværs af landegrænser.

Der kan bl.a. hentes inspiration fra Ny Nordisk Skole, der er et dansk tværgående forandringsprojekt for hele dagtilbuds- og uddannelsessystemet, der med afsæt i danske og nordiske værdier udfordrer den pædagogiske og læringsmæssige praksis. Formålet med Ny Nordisk Skole er at udfordre alle børn og unge, så de bliver så dygtige, de kan, mindske betydningen af social baggrund i forhold til faglige resultater og styrke tilliden til dagtilbud og uddannelser med respekt for professionel viden og praksis. 
Det nordiske fællesskab bygger på et historisk, kulturelt og sprogligt fællesskab. Forståelsen af den nordiske kultur og nabosprogene dansk, svensk og norsk bidrager til en øget fællesskabsfølelse og fremmer mobiliteten i regionen. På undervisningssiden er børn og unges lytteforståelse en prioriteret indsats, men det er vigtigt, at sprog og kultur sammentænkes for at styrke oplevelsen af det nordiske fællesskab. Derfor er der i Nordisk Ministerråd nedsat en tværfaglig ad hoc gruppe, der skal se på synergien mellem satsningerne på henholdsvis kultur- og undervisningssiden. $\mathrm{Og}$ for at få så mange erfaringer og indspil fra aktører på sprogområdet for at kunne styrke den fremtidige indsats, vil der blive arrangeret et kontaktseminar for centrale aktører fra begge sektorer.

\section{Danmark vil under sit formandskab:}

- Afholde en konference om uddannelseseksport med deltagelse fra de nordiske uddannelsesinstitutioner, tænketanke, virksomheder og samarbejdspartnere med udveksling af ideer og erfaringer samt fokus på, hvordan vi sammen som Norden kan styrke de nationale indsatser.

- Fortsætte den nordiske dialog om ligestilling i uddannelse og forskning i Ministerrådet for Uddannelse og Forskning (MR-U) og udveksle erfaringer om best practice.

- Sikre, at der er kobling i projektet om køn, ligestilling og uddannelse i Norden under Ministerrådet for Ligestilling (MR-JÄM) til Ministerrådet for Uddannelse og Forskning (MR-U).

- Opfordre til tværfagligt og tværnordisk netværkssamarbejde mellem dagtilbud, skoler og ungdomsuddannelser om konkrete forandringsprojekter og temaer med inspiration fra Ny Nordisk Skole.

- Samarbejde med Nordisk Ministerråds Sekretariat om at arrangere et tværsektorielt kontaktseminar for aktører i undervisnings- og kultursektoren med henblik på at opbygge netværk og styrke det fælles værdiggrundlag, som ligger i nordisk sprog- og kulturidentitet. 


\section{Det blå Arktis - Norden som aktør i Arktis}

I tråd med Danmarks overordnede formandsskabsprogram for 2015 og Kongeriget Danmarks Strategi for Arktis 2011-2020 tager Arktis i stigende grad plads i undervisnings-, uddannelses- og forskningspolitikken.

I takt med klimaforandringerne forandres vilkårene for befolkningerne i Arktis. Med en stor del af land- og havområder beliggende i den arktiske region, står Norden med en række fælles muligheder og udfordringer. Norden skal tage aktiv del i bestræbelserne på at sikre en bæredygtig udvikling i regionen med landenes befolkninger i centrum. For den stigende globale interesse i nye sejlruter, forekomster af olie, gas og sjældne jordarter må ikke ske på bekostning af lokalsamfundenes bæredygtighed.

Nordens mangeårige tradition for samarbejde og vidensdeling på tværs af en række fagområder kan også komme det arktiske uddannelses- og forskningssamarbejde til gode og $i$ et bredere perspektiv understøtte regionens fredelige og bæredygtige udvikling.

Eksempelvis kan Nordens forskningstradition inden for klima -, energi - og miljøløsninger fremhæves ligesom velfærdsområdet og freds- og konfliktforskning. Det arktiske erhvervsliv kan styrkes gennem bedre infrastruktur og sejladssikkerhed med blik for havmiljø og biodiversitet. NordForsks forskningsprogram Ansvarlig udvikling af Arktis er et bud på, hvorledes tværfaglige, nordiske centres of excellence kan bruges til at løse arktiske samfundsudfordringer. At bryde negativ social arv, sikre social mobilitet og inklusion i særligt de mindre, arktiske samfund er andre indsatsområder, som et styrket nordisk undervisnings - og uddannelsessamarbejde kan understøtte. Nordisk støtte til UArctic - de arktiske universiteter - har således forbedret lokalbefolkningernes uddannelsesmuligheder.

Der vil endvidere blive sat fokus på at fremme børn og unges forståelse for rigsfælleskabet, udviklingen i Nordatlanten, de arktiske folk og den arktiske dimension af de nordiske landes udvikling. Det vil ske gennem udvikling af elektroniske undervisningsmidler om den historiske, samfundsmæssige og kulturelle sammenhæng mellem Færøerne, Grønland, Norge, Island og Danmark, der ligger til grund for nutidens danske rigsfælleskab. 


\section{Danmark vil under sit formandskab:}

- Følge op på Nordisk Ministerråds arktiske samarbejdsprogram for 2015 til 2017 og prioritere arktiske forhold $\mathrm{i}$ andre fora herunder særligt $\mathrm{i}$ Arktisk Råd og i EU.

- Arrangere en forskningskonference med det formål at vurdere det aktuelle og fremtidige behov for tiltag, der øger forskning i sikkerheden i Arktis og samtidig styrker de arktiske folks og samfunds tilpasningsevne og robusthed gennem samarbejde mellem de arktiske stater.

- Sætte fokus på rigsfællesskabets historie og relationerne mellem de arktiske befolkninger i Nordatlanten og invitere til en to-dages arbejdskonference for fagfolk med henblik på at udvikle undervisningsmateriale for grundskolernes ældste klassetrin og ungdomsuddannelserne. 
Nordisk Ministerråd

Ved Stranden 18

DK-1061 København K

www.norden.org

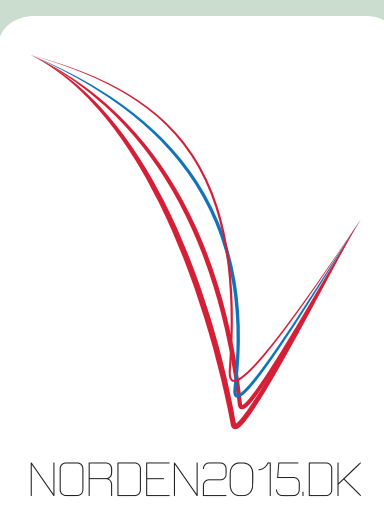

Yderligere information om Danmarks formandskab fås på www.norden2015.dk

Udenrigsministeriet Sekretariatet for Ministeren for Nordisk Samarbejde norden2015@um.dk

Asiatisk Plads 2

DK-1448 København K Danmark

Telefon: +4533920000

ANP 2014:774

ISBN 978-92-893-3903-2 (PRINT)

ISBN 978-92-893-3904-9 (PDF)

http://dx.doi.org/10.6027/ANP2014-774 